\title{
Polymorphisms of the cytokine genes TGFB1 and IL10 in a mixed-race population with Crohn's disease
}

\author{
Neogelia Pereira Almeida ${ }^{1,2,3^{*}}$, Genoile Oliveira Santana ${ }^{1,2}$, Tamara Celi Almeida ${ }^{1}$, Maria Teresita Bendicho ${ }^{1}$, \\ Denise Carneiro Lemaire ${ }^{1}$, Mauricio Cardeal ${ }^{1}$ and André Castro Lyra ${ }^{1}$
}

\begin{abstract}
Background: Most Crohn's disease (CD) genes discovered in recent years are associated with biological systems critical to the development of this disease. TGFB1 and IL10 are cytokines with important roles in CD. The aim of this study was to evaluate the association between CD, its clinical features and TGFB1 and IL10 gene polymorphisms.

Methods: This case-control study enrolled 91 patients and 91 controls from the state of Bahia, Brazil. Five single nucleotide polymorphisms (SNPs) were studied in the TGFB1 gene (codon 10 T>C - rs1800470; codon 25 G > C rs1800471) and IL10 gene (-1082 A > G - rs1800896; -819 T > C - rs1800871; -592 A > C - rs1800872). An analysis of the genetic polymorphisms was performed using a commercial kit. A comparison of allele frequencies and genotypes was estimated by calculating the odds ratio (OR) with a confidence interval adjusted via the Bonferroni test for a local alpha of $1 \%$. A stratified analysis was applied for gender, race and smoking history. Patients with CD were characterized according to the Montreal classification.

Results: The C allele and CC genotype of the TGFB1 gene rs 1800470 were both significantly associated with CD. The stratified analysis showed no confounding factors for the co-variables of gender, race and smoking history. The IL10 gene rs $1800896 \mathrm{G}$ allele was significantly associated with age at diagnosis of CD, while the T allele of the IL10 gene rs 1800871 was significantly associated with perianal disease. The SNPs rs1800871 and rs1800872 were in 100\% linkage disequilibrium.
\end{abstract}

Conclusions: TGFB1 gene polymorphisms may be associated with susceptibility to the development of CD, and IL10 gene polymorphisms appear to influence the CD phenotype in this admixed population.

Keywords: Crohn's disease, Polymorphism, TGFB1, IL10

\section{Background}

Crohn's disease (CD) pathogenesis is multifactorial, and there appears to be a significant interaction between its genetic, environmental and immunological factors [1,2]. The critical importance of immune regulation in inflammatory bowel disease (IBD) has been recognized, and impairment in immune tolerance to the intestinal microbiota appears to be the primary defect associated with this disease [3,4]. It is interesting to note that TGFB1 and IL10 are the two major immune regulatory cytokines

\footnotetext{
* Correspondence: neoalmeida@yahoo.com.br

${ }^{1}$ Federal University of Bahia, Salvador, Brazil

${ }^{2}$ Gastroenterology Unit, Roberto Santos General Hospital, Salvador, Bahia, Brazil Full list of author information is available at the end of the article
}

[5-10]. Most CD genes discovered in recent years are associated with biological systems critical to the development of $C D$, such as innate and adaptive immunity, stress response, autophagy and mucosal barrier [11,12].

TGFB1 is fundamental in maintaining the intestinal epithelial cell homeostasis through its action on modulating $\mathrm{T}$ cell activity, dendritic cell function and apoptosis $[5-7,10]$. The central role of IL10 in the balance of intestinal mucosa immunology is its ability to inhibit the production of proinflammatory cytokines and to regulate the differentiation and proliferation of $\mathrm{T}$ and $\mathrm{B}$ lymphocytes and NK and antigen presenting cells [5,8-10]. Both TGFB1 and IL10 cytokines play important roles in CD. Animal studies demonstrated the importance of these

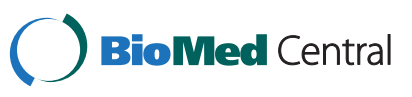


cytokines in the development of experimental colitis $[6,13]$. The neutralization of TGFB1 increases Th1 and Th17 responses, and IL10 constrains Th17 cells in patients with CD [6,14]. A defect in TGFB1 production has been observed in patients with CD, and the deregulation of IL10 has been associated with early-onset and severe CD $[15,16]$. TGFB1 is also involved in fibrosis and stricture formation in $\mathrm{CD}$ [17].

Differences in cytokine production have been linked to polymorphisms in gene promoter regions [18-22]. Individual differences in cytokine synthesis could explain the susceptibility to CD and its phenotypic heterogeneity. Studies about the influence of TGFB1 and IL10 genetic polymorphisms on the pathogenesis of inflammatory bowel disease (IBD) have been published with controversial results, and most subjects were Caucasians [19,20,23-30].

The TGFB1 gene has at least two polymorphisms located in the exon 1 region at rs1800470 and rs1800471, which are the most frequently studied polymorphisms in our local population [31,32]. A previous Australian study showed an association between polymorphisms at rs1800471 and CD [33]. The most commonly evaluated polymorphisms in the IL10 gene are identified in the promoter regions from rs18004896, rs1800871 and rs1800872 [19,20,23,25-32]. These genes are closely related to the expression of IL10 $[18,20]$.

The aim of this study was to analyze the association between CD and the TGFB1 (codon $10 \mathrm{~T}>\mathrm{C}-\mathrm{rs} 1800470$; codon $25 \mathrm{G}>\mathrm{C}-\mathrm{rs} 1800471)$ and $\operatorname{IL10}(-1082 \mathrm{~A}>\mathrm{G}-\mathrm{rs} 1$ 800896; -819 T > C - rs1800871; -592 A > C - rs1800872) gene polymorphisms and to examine the association between these polymorphisms and the clinical features of $\mathrm{CD}$, such as age at diagnosis, location, and behavior of the disease in a mixed-race population.

\section{Methods}

This was a case-control study. We evaluated patients from outpatient gastroenterology clinics at the University Hospital Prof. Edgard Santos and at the General Hospital Roberto Santos in Salvador, Bahia. The patients and controls were enrolled between March 2006 and May 2007.

We included patients 18 years or older who had a diagnosis of Crohn's disease, as established by the clinical, radiological, endoscopic and histopathological features described in the criteria of Lennard-Jones [34]. We excluded first-degree relatives of patients who had been included in the study and patients with indeterminate colitis. The classification for CD was based on the Montreal criteria, which include age at diagnosis, behavior, and location [35]. The ethnic profile was performed using the Krieger criteria [36]. Patients were considered smokers if they had smoked seven or more cigarettes per week for at least one year.

The control group comprised individuals from either outpatient clinics who were 18 years old or older, had been evaluated at the same period of time and had a diagnosis of gastroesophageal reflux disease (GERD) (81 patients) or functional dyspepsia (10 patients). These subjects were required not to have had any neoplastic, infectious or inflammatory diseases, peptic ulcers, diarrhea, hematochezia, fistulas, family history of IBD, or abdominal pain without a specific diagnosis.

To obtain genomic DNA, $10 \mathrm{~mL}$ of whole blood was collected from each patient and stored at $-4^{\circ} \mathrm{C}$ in EDTA tubes until DNA extraction. Genomic DNA was purified using the commercial EZ-DNA kit (Biological Industries, Kibbuts Beit Haemek, Israel) according to the manufacturer's instructions. The five single nucleotide polymorphisms (SNPs) studied were rs1800470 (codon $10 \mathrm{~T}>\mathrm{C}$ ) and rs1800471 (codon $25 \mathrm{G}>\mathrm{C}$ ) in the TGFB1 gene and rs1800896 (-1082 A > G), rs1800871 (-819 T $>$ C), and rs1800872 $(-592 \mathrm{~A}>\mathrm{C})$ in the IL10 gene. The SNPs were genotyped with the Cytokine Genotyping Tray Kit (One Lambda, Canoga Park, CA) according to the manufacturer's instructions. The results were interpreted using maps of the genotyping plates supplied by the manufacturer.

Adherence to the Hardy-Weinberg equilibrium for each polymorphism was tested for both case and control groups using the program GENEPOP [37]. A comparison of allele frequencies and genotypes in the different groups was estimated by calculating the odds ratio (OR) with an adjusted confidence interval (CI) of $99.8 \%$ and global $\alpha=0.2 \%$ for a local alpha of $1 \%$ (Bonferroni adjustment). The covariables of interest were gender, racial group (evaluated as Whites or African-descendants), and smoking. To analyze the effects of confounding factors and modifiers on the main association, we performed a stratified analysis using estimated ORs with 99\% confidence intervals, MantelHaenszel adjusted ORs and the Mantel-Haenszel chisquare test. Because no significance was found for a local alpha of $1 \%$, the Bonferroni correction was not considered. Logistic regression was not performed due to insufficient data. To evaluate the association between the polymorphisms and phenotype characteristics of $C D$, the OR was calculated and Fisher's exact test was performed, yielding p-values that were adjusted using the Bonferroni method. The global alpha was $0.167 \%$, and the CI was adjusted to 99.83\% considering a local alpha of $1 \%$.

Informed written consent was obtained from all subjects, and the study protocol was approved by the Ethics Committee of the Institution (Maternidade Climério de Oliveira - Federal University of Bahia).

\section{Results}

We evaluated 182 subjects, of whom 91 had a definite diagnosis of $\mathrm{CD}$ and 91 were controls. The mean age of the patients with $\mathrm{CD}$ was $38.0 \pm 12.8$ years (range $18-$ 75 years, median 37 years), while the control patients had a mean age of $50.3 \pm 13.6$ years (range $21-88$ years, median 
50 years). Jewish descent was reported by 3 patients with $\mathrm{CD}$. The distribution of racial groups was similar between the cases and controls. There was a higher frequency of smoking history (current or previous) among the controls. The demographic and clinical characteristics of CD patients and controls are shown in Table 1 . When gender, race, and smoking history were compared, there were no statistically significant differences between the cases and controls (data not shown).

All polymorphisms adhered to the Hardy-Weinberg equilibrium in both the case and control groups. The allele frequencies and genotype distribution for TGFB1 polymorphisms (rs1800470, rs1800471) in the CD patients and controls are shown in Table 2. The $\mathrm{C}$ allele of rs1 800470 was more frequent in the case group and was associated with $\mathrm{CD}(\mathrm{p}=0.001, \mathrm{OR}=2.19,99.8 \% \mathrm{CI}=1.1$ 4.42). The CC genotype of rs 1800470 was more frequent

Table 1 Demographic and clinical characteristics of the CD patients and controls

\begin{tabular}{|c|c|c|}
\hline & 91 Cases (n\%) & 91 Controls ( $n \%)$ \\
\hline \multicolumn{3}{|l|}{ - Age } \\
\hline Mean \pm SD & $38 \pm 12.8$ & $50,3 \pm 13.6$ \\
\hline \multicolumn{3}{|l|}{ - Gender } \\
\hline Female & $54(59.3)$ & $67(73.6)$ \\
\hline Male & $37(40.7)$ & $24(26.4)$ \\
\hline \multicolumn{3}{|l|}{ - Race group } \\
\hline African-descendent & $80(87.9)$ & $82(90.1)$ \\
\hline White & $11(12.1)$ & $09(09.9)$ \\
\hline \multicolumn{3}{|l|}{ · Smoking } \\
\hline No & $71(78.0)$ & $64(70.3)$ \\
\hline Yes & $20(22.0)$ & $27(29.7)$ \\
\hline \multicolumn{3}{|l|}{ - Age at diagnosis, $n=91$} \\
\hline$A 1 \leq 16$ years & $12(13.2)$ & \\
\hline A2 $17-40$ years & $55(60.4)$ & \\
\hline$A 3>40$ years & $24(26.4)$ & \\
\hline \multicolumn{3}{|l|}{ - Location , $n=82$} \\
\hline L1 \pm L4 Ileum & $17(20.7)$ & \\
\hline L2 \pm L4 Colon & $21(25.6)$ & \\
\hline L3 \pm L4 lleum and colon & $43(52.4)$ & \\
\hline $\begin{array}{l}\text { L4 Isolated upper } \\
\text { gastrointestinal tract }\end{array}$ & $1(1.3)$ & \\
\hline \multicolumn{3}{|l|}{ - Behavior, $\mathrm{n}=90$} \\
\hline $\begin{array}{l}\text { B1 } \pm P \text { Non-stricturing, } \\
\text { non-penetrating }\end{array}$ & $62(68.9)$ & \\
\hline$B 2 \pm P$ Stricturing & $13(14.4)$ & \\
\hline B3 \pm P Penetrating & $15(16.7)$ & \\
\hline P Perianal disease modifier & $40(44.4)$ & \\
\hline
\end{tabular}

$\mathrm{n}$ (\%) Number of individuals (percent). in the patients with $\mathrm{CD}$ compared with the controls $(\mathrm{p}=$ 0.001, $\mathrm{OR}=4.05,99.8 \% \mathrm{CI}=1.31-13.2$ ). These results were statistically significant after a Bonferroni correction. We did not observe any association between TGFB1 genotypes and the $\mathrm{CD}$ phenotype.

The allele frequencies and genotypes of the IL10 polymorphisms (rs1800896, rs1800871 and rs1800872) were similar for both the cases and controls (Table 3). The SNPs rs1800871 and rs1800872 were in 100\% linkage disequilibrium. The frequencies of the alleles for these IL10 SNPs according to the phenotype characteristics of CD are shown in Table 4. The G allele of rs1800896 was more frequent in patients who were 16 years old or younger at diagnosis $(\mathrm{p}=0.001, \mathrm{OR}=4.32,99.83 \% \mathrm{CI}=$ 1.0022-18.62). An analysis of the association between disease location and IL10 SNPs was not statistically significant (data not shown). We also found a significantly higher frequency of the T allele of rs1800871 in the IL10 gene in patients with perianal disease $(\mathrm{p}<0.0001, \mathrm{OR}=$ 7.7, 99.83\% CI $=2.53-26.90$ ). These results were statistically significant after a Bonferroni correction.

The stratified analysis by gender, racial group and smoking history variables in our study showed that none of these factors modified the effect or confounded the association between the studied polymorphisms and CD.

\section{Discussion}

When conducting a case-control genetic association study, the selection of controls is an important issue. This control group should comprise subjects of the same population as that of the cases enrolled [38]. The control group comprised patients treated at the same clinic with similar epidemiological characteristics who were from the same geographical area and had a diagnosis of a clinical condition not associated with the studied polymorphisms. In addition, the controls were prospectively evaluated in the same period of time in which the cases were enrolled. GERD is a motor disorder not genetically determined, and no studies have shown an association between the studied polymorphisms and functional dyspepsia. Both the case and control groups were similar in terms of gender and race. Previous studies from Brazil have shown a genetic admixture from Portuguese, Amerindian and African genetic backgrounds in the population of all studied geographic areas, including the population of Bahia, regardless of the skin color of the individuals $[39,40]$.

Animal studies have shown that a reduction in TGFB1 affects oral tolerance and results in impaired mucosal immunity [41]. Del Zotto et al. performed an interesting study in Italy and observed that low levels of TGFB1 were present in the intestinal lamina propria of $C D$ patients compared with controls [15]. Our polymorphism analysis of the TGFB1 cytokine gene showed a positive association between CD and the C allele of SNP rs1800470. However, 
Table 2 Allele frequencies and genotype distribution for the TGFB1 polymorphisms in CD patients and controls

\begin{tabular}{|c|c|c|c|c|c|c|}
\hline & 91 Cases n (\%) & 91 Controls n (\%) & $O R$ & {$[99.8 \% \mathrm{Cl}]$} & $P_{B}$ & $P$ value \\
\hline \multicolumn{7}{|c|}{ - rs1800470 (codon $10 \mathrm{~T}>\mathrm{C})$} \\
\hline T allele & $81(45.5 \%)$ & $116(63.7 \%)$ & 2.19 & {$[1.10-4.42]$} & 0.005 & 0.001 \\
\hline C allele & $101(55.5 \%)$ & $66(36.3 \%)$ & & & & \\
\hline \multicolumn{7}{|c|}{ - Genotype } \\
\hline$\pi$ & $22(24.1 \%)$ & $39(42.8 \%)$ & Reference & & & \\
\hline TC & $37(40.7 \%)$ & $38(41.8 \%)$ & 1.73 & {$[0.66-4.78]$} & 0.820 & 0.164 \\
\hline CC & $32(35.2 \%)$ & $14(15.4 \%)$ & 4.05 & {$[1.31-13.20]$} & 0.005 & 0.001 \\
\hline \multicolumn{7}{|c|}{ - rs1800471 (codon 25 G > C) } \\
\hline G allele & $166(91.2 \%)$ & $176(96.7 \%)$ & 2.83 & {$[0.77-10.89]$} & 0.150 & 0.030 \\
\hline C allele & $16(8.8 \%)$ & $6(3.3 \%)$ & & & & \\
\hline \multicolumn{7}{|c|}{ - Genotype } \\
\hline GG & 77 (84.6\%) & 85 (93.4\%) & Reference & & & \\
\hline GC & $12(13.2 \%)$ & $6(6.6 \%)$ & 2.21 & {$[0.53-11.08]$} & 0.710 & 0.142 \\
\hline CC & $2(2.2 \%)$ & $0(0 \%)$ & $\cdots \cdots \cdots$ & $\cdots \cdots \cdots \cdots$ & $\ldots \ldots . .$. & $\cdots \cdots \cdots \cdots$ \\
\hline
\end{tabular}

$\mathrm{n}$ (\%) Number of alleles or genotypes (percent).

$P_{B}$ Bonferroni adjustment.

......... Insufficient number.

studies from Europe and North America have failed to show an association between TGFB1 polymorphisms and CD $[23,24,42]$. Additionally, the TGFB1 gene has not been associated with $\mathrm{CD}$ in genome-wide association studies (GWAS) $[11,12]$. The confirmed CD susceptibility loci explained only $23.2 \%$ of the disease heritability [11]. These findings could suggest the existence of other genetic variations not captured via GWAS. One possible explanation for the differences between our results and those previously reported is that we investigated African-descent CD patients while the other studies evaluated Caucasian populations. Therefore, the TGFB1 gene could be directly associated with susceptibility to $C D$ in this population or in a linkage disequilibrium with other genetic markers. This conclusion is biologically plausible, but additional studies are needed to validate these data. The allele frequencies of rs1800470 in TGFB1 in our CD patients were similar to the frequency of a healthy control group reported by Pereira et al., who evaluated genetic polymorphisms in patients with hepatitis $C$ in the State of Bahia [32]. This

Table 3 Allele frequencies and genotype distribution for the IL10 polymorphisms in CD patients and controls

\begin{tabular}{|c|c|c|c|c|c|}
\hline & 91 cases $\mathrm{n}(\%)$ & 91 controls $\mathrm{n}(\%)$ & OR & {$[99 \% \mathrm{Cl}]$} & $P$ value \\
\hline \multicolumn{6}{|c|}{ - rs1800896 (-1082 A > G) } \\
\hline Aallele & $116(63.7 \%)$ & $123(67.6 \%)$ & 1.19 & {$[0.66-2.14]$} & 0.44 \\
\hline G allele & $66(36.3 \%)$ & $59(32.4 \%)$ & & & \\
\hline \multicolumn{6}{|c|}{ - Genotype } \\
\hline AA & $41(45.0 \%)$ & $40(44.0 \%)$ & Reference & & \\
\hline GA & $34(37.4 \%)$ & $43(47.2 \%)$ & 0.77 & {$[0.32-1.84]$} & 0.42 \\
\hline GG & $16(17.6 \%)$ & $8(8.8 \%)$ & 1.95 & {$[0.52-7.45]$} & 0.16 \\
\hline \multicolumn{6}{|c|}{ - rs1800871 $(-819 \mathrm{~T}>\mathrm{C})^{*}$} \\
\hline C allele & $116(63.7 \%)$ & $106(58.2 \%)$ & 0.79 & {$[0.45-1.41]$} & 0.28 \\
\hline Tallele & $66(36.3 \%)$ & $76(41.8 \%)$ & & & \\
\hline \multicolumn{6}{|c|}{ - Genotype } \\
\hline CC & $36(39.6 \%)$ & $28(30.8 \%)$ & Reference & & \\
\hline$C T$ & $44(48.4 \%)$ & $50(54.9 \%)$ & 0.68 & {$[0.28-1.66]$} & 0.24 \\
\hline$\Pi$ & $11(12.0 \%)$ & $13(14.3 \%)$ & 0.66 & {$[0.17-2.46]$} & 0.38 \\
\hline
\end{tabular}

$\mathrm{n}(\%)$ Number of alleles or genotypes (percent).

*SNPs rs1800871 and rs1800872 were in 100\% linkage disequilibrium. 
Table 4 Allele frequencies of the IL10 polymorphisms according to the Crohn's disease phenotypes

\begin{tabular}{|c|c|c|c|c|c|c|c|c|c|}
\hline & \multirow{4}{*}{$\mathrm{N}$} & \multirow{2}{*}{\multicolumn{4}{|c|}{$\begin{array}{l}\text { rs1800896 } \\
\text { AlleleG }\end{array}$}} & \multirow{2}{*}{\multicolumn{3}{|c|}{$\begin{array}{l}\text { rs1800871* } \\
\text { Allele T }\end{array}$}} & \multirow{4}{*}{$P$ value } \\
\hline & & & & & & & & & \\
\hline & & n (\%) & OR & $P_{B}$ & $P$ value & n (\%) & OR & $P_{B}$ & \\
\hline & & \multicolumn{3}{|c|}{$[99.83 \mathrm{Cl}]$} & \multirow{2}{*}{\multicolumn{5}{|c|}{ [99.83 Cl] }} \\
\hline \multicolumn{5}{|c|}{ - Age at diagnosis } & & & & & \\
\hline \multirow[t]{2}{*}{$\mathrm{A} 1$} & \multirow[t]{2}{*}{12} & \multirow[t]{2}{*}{$16(66.7)$} & 4.32 & \multirow[t]{2}{*}{0.006} & \multirow[t]{2}{*}{0.001} & \multirow[t]{2}{*}{$6(25)$} & 0.54 & \multirow[t]{2}{*}{1.000} & \multirow[t]{2}{*}{0.260} \\
\hline & & & {$[1.0022-8.62]$} & & & & [0.07 - 2.59] & & \\
\hline$A 2+A 3$ & 79 & 50 (31.6) & & & & $60(38)$ & & & \\
\hline \multicolumn{10}{|c|}{ - Behavior } \\
\hline \multirow[t]{2}{*}{ B1 } & \multirow[t]{2}{*}{62} & \multirow[t]{2}{*}{$42(33.9)$} & 0.68 & \multirow[t]{2}{*}{1.000} & \multirow[t]{2}{*}{0.316} & \multirow[t]{2}{*}{$47(37.9)$} & 1.4 & \multirow[t]{2}{*}{1.000} & \multirow[t]{2}{*}{0.401} \\
\hline & & & {$[0.23-2.05]$} & & & & {$[0.46-4.58]$} & & \\
\hline$B 2+B 3$ & 28 & $24(42.9)$ & & & & $17(30.4)$ & & & \\
\hline \multirow[t]{2}{*}{$P$} & \multirow[t]{2}{*}{40} & $30(37.5)$ & 1.07 & \multirow[t]{2}{*}{1.000} & \multirow[t]{2}{*}{0.877} & \multirow[t]{2}{*}{$48(60)$} & 7.77 & \multirow[t]{2}{*}{$<0.0001$} & \multirow[t]{2}{*}{$<0.0001$} \\
\hline & & & [0.38 - 2.96] & & & & {$[2.53-26.90]$} & & \\
\hline
\end{tabular}

$\mathrm{A} 1 \leq 16$ years, A2 17-40 years, A3 > 40 years, B1 Non-stricturing, non-penetrating, B2 Stricturing, B3 Penetrating, P Perianal disease modifier. $\mathrm{N}$ Number of patients, $\mathrm{n}$ (\%) Number of alleles (percent), $\mathrm{P}_{B}$ Bonferroni adjustment.

*SNPs rs 1800871 and rs 1800872 were in $100 \%$ linkage disequilibrium.

result could be because a family history of IBD was not obtained in the hepatitis $\mathrm{C}$ study. A patient's family history of IBD was considered an exclusion criterion in our control group.

TGFB1 is a potent fibrogenic agent that induces the proliferation of fibroblasts and the synthesis of collagen and extracellular matrix $[43,44]$. Changes in TGFB1 signaling have also been identified in the mucosa overlying strictures in CD [17]. Previous reports have suggested a role for TGFB1 polymorphisms in stricturing $\mathrm{CD}$ and a shorter time to intestinal resection [33]. However, in agreement with our findings, Cantor et al. found no association between the TGFB1 polymorphism and the phenotypic characteristics of CD [23].

The development of spontaneous chronic enterocolitis in genetically modified mice that do not produce the cytokine IL10 has long been known [5,13,16]. Many studies have shown no association between several IL10 polymorphisms and susceptibility to CD [23,25-27,45]. However, studies from Spain, New Zealand, and Mexico showed that these IL10 polymorphisms were associated with CD susceptibility $[19,28,46]$. More recently, a meta-analysis showed an association between the SNPs from rs1800896 and CD susceptibility [47]. We have not been able to replicate these findings in our sample.

The IL10 gene has been identified as a novel CD locus in GWAS studies [11,12]. Experimental studies have shown that a low production of IL10 is associated with more severe and complex CD [16]. Although usually considered an inhibitory cytokine, IL10 also stimulates B-cell proliferation [48]. Genetic studies evaluating CD patients demonstrated an association between IL10 polymorphisms and the severity of disease, including stricturing behavior and pediatric onset [30,49]. We observed a positive association between the $\mathrm{G}$ allele of rs1800896 and age at diagnosis of $\mathrm{CD}$. Some studies indicated that the $\mathrm{G}$ allele was associated with increased IL10 production $[18,20]$. The SNPs at rs1800896 appear to dictate early-onset disease, in which the development is likely influenced by genetic rather than environmental factors. The other studied IL1O SNP (rs1800871) was associated with perianal disease, suggesting that it may be useful in predicting $\mathrm{CD}$ behavior. It is possible that the association between specific IL10 promoter polymorphisms and severe $\mathrm{CD}$ may be correlated with the stimulatory effects of $I L 10$, but additional functional investigation is necessary to confirm this hypothesis.

$\mathrm{CD}$ is considered a frequent disease in Caucasian populations; however, most $\mathrm{CD}$ patients in our studied population were not Caucasian. The study of CD in different populations may increase our understanding about the genetics and environmental factors that might interfere with the development $\mathrm{CD}$.

\section{Conclusion}

In conclusion, this study has shown that TGFB1 polymorphisms may be associated with susceptibility to $C D$, while IL10 polymorphisms may influence CD phenotypes. Thus, the polymorphic sites of both genes appear to be particularly important in our population. However, further multicenter studies with larger samples are needed to evaluate the reproducibility of our findings. $\mathrm{CD}$ is a disease that greatly impacts patient quality of life, and despite its rising frequency, the pathophysiologic mechanisms of $C D$ are unclear and present a challenge. A better understanding of the various genetic polymorphisms that affect different populations may eventually lead to the better management of CD. 


\section{Availability of supporting data}

We have no supporting data to include in an open access repository.

\section{Competing interests}

The authors declare that they have no competing interests.

\section{Authors' contributions}

ANP and SGO performed the majority of this work; ATC performed the data collection; CM provided the analytical tools; LAC was involved in writing and editing the manuscript; BMTF and LDC performed DNA extraction and genotyping. All authors read and approved the final manuscript.

\section{Acknowledgements}

We are thankful to the following persons for their assistance and/or support for this study: Lidiane Bianca dos Reis, Mabel Proence Pereira Lopes, Maria Victória Prieto, Jorge Carvalho Guedes, and Cristiane Fortes.

\section{Author details}

${ }^{1}$ Federal University of Bahia, Salvador, Brazil. ${ }^{2}$ Gastroenterology Unit, Roberto Santos General Hospital, Salvador, Bahia, Brazil. ${ }^{3}$ Alameda dos Jasmins, n-220, Apt-1902, Cidade Jardim/Candeal, CEP 40296200, Salvador, Bahia, Brazil.

Received: 4 November 2012 Accepted: 25 September 2013 Published: 27 September 2013

\section{References}

1. Podolsky DK: Inflammatory bowel disease. N Engl J Med 2002, 347:417-429.

2. Lakatos PL, Fischer S, Lakatos L, Gal I, Papp J: Current concept on the pathogenesis of inflammatory bowel disease-crosstalk between genetic and microbial factors: Pathogenic bacteria and altered bacterial sensing or changes in mucosal integrity take "toll"? World J Gastroenterol 2006, 12:1829-1841

3. Bamias G, Caminelli F: Immunopathogenesis of inflammatory bowel disease: current concepts. Curr Opin Gastroenterol 2007, 23:365-369.

4. Smith AM, Rahman FZ, Hayee B, Graham SJ, Marks DJ, Sewell GW, Palmer CD, Wilde J, Foxwell BM, Gloger IS, Sweeting T, Marsh M, Walker AP, Bloom SL, Segal AW: Disordered macrophage cytokine secretion underlies impaired acute inflammation and bacterial clearance in Crohn's disease. J Exp Med 2009, 206:1883-1897.

5. Sanchez-Munoz F, Domingues-Lopez A, Yamamoto-Furusho JK: Role of cytokines in inflammatory bowel disease. World J Gastroenterol 2008, $14: 4280-4288$

6. MacDonald TT, Vossenkaemper A, Fantini M, Monteleone G: Reprogramming the immune system in IBD. Dig Dis 2012, 30:392-395.

7. Dieckgraefe BK, Stenson WF, Alpers DH: Gastrointestinal epithelial response to injury. Curr Opin Gastroenterol 1996, 12:109-114.

8. Papadakis KA, Targan SR: Role of cytokines in the pathogenesis of inflammatory bowel disease. Annu Rev Med 2000, 51:289-298.

9. Grutz G: New insights into the molecular mechanism of interleukin 10 mediated immunosupression. J Leukoc Biol 2005, 21:263-265.

10. Levings MK, Bacchetta R, Schulz U, Roncarolo MG: The role of IL-10 and TGF-beta in the differentiation and effector function of T regulatory cells. Int Arch Allergy Immunol 2002, 129:263-276.

11. Franke A, McGovern DP, Barrett JC, Wang K, Radford-Smith GL, Ahmad T, Lees CW, Balschun T, Lee J, Roberts R, Anderson CA, Bis JC, Bumpstead S, Ellinghaus D, Festen EM, Georges M, Green T, Haritunians T, Jostins L, Latiano A, Mathew CG, Montgomery GW, Prescott NJ, Raychaudhuri S, Rotter Jl, Schumm P, Sharma Y, Simms LA, Taylor KD, Whiteman D, et al: Genome-wide meta-analysis increases to 71 the number of confirmed Crohn's disease susceptibility loci. Nat Genet 2010, 42:1118-1125.

12. Jostins L, Ripke S, Weersma RK, Duerr RH, McGovern DP, Hui KY, Lee JC, Schumm LP, Sharma Y, Anderson CA, Essers J, Mitrovic M, Ning K, Cleynen I, Theatre E, Spain SL, Raychaudhuri S, Goyette P, Wei Z, Abraham C, Achkar JP, Ahmad T, Amininejad L, Ananthakrishnan AN, Andersen V, Andrews JM, Baidoo L, Balschun T, Bampton PA, Bitton A, et al: Host-microbe interactions have shaped the genetic architecture of inflammatory bowel disease. Nature 2012, 491:119-124.

13. Kuhn R, Lohler J, Rennick D, Rajewsky K, Muller W: Interleukin-10-deficient mice develop chronic enterocolitis. Cell 1993, 75:263-274.
14. Wilke CM, Wang L, Wei S, Kryczek I, Huang E, Kao J, Lin Y, Fang J, Zou W: Endogenous interleukin-10 constrains Th17 cells in patients with inflammatory bowel disease. J Transl Med 2011, 9:217.

15. Del Zotto B, Mumolo G, Pronio AM, Montesani C, Tersigni R, Boirivant M: TGF-beta1 production in inflammatory bowel disease: differing production patterns in Crohn's disease and ulcerative colitis. Clin Ex Immuno 2003, 134:120-126.

16. Correia I, Veny M, Esteller M, Piqué JM, Yagüe J, Panés J, Salas A: Defective IL-10 production in severe phenotypes of Crohn's disease. J Leukoc Biol 2009, 85:896-903.

17. Di Sabatino A, Jackson CL, Pickard KM, Buckley M, Rovedatti L, Leakey NA, Picariello L, Cazzola P, Monteleone G, Tonelli F, Corazza GR, MacDonald TT, Pender SL: Transforming growth factor beta signaling and matrix metalloproteinases in the mucosa overlying Crohn's disease strictures. Gut 2009, 58:777-789.

18. Koss K, Satsangi J, Fanning GC, Welsh Kl, Jewell DP: Cytokine (TNFa, LTa and IL-10) polymorphisms in inflammatory bowel diseases and normal controls: differential effects on production and allele frequencies. Genes Immun 2000, 1:185-190.

19. Wang AH, Lam WJ, Han DY, Ding Y, Hu R, Fraser AG, Ferguson LR, Morgan AR: The effect of IL-10 genetic variation and interleukin 10 serum levels on Crohn's disease susceptibility in a New Zealand population. Hum Immunol 2011, 72:431-435.

20. Tagore A, Gonsalkorale WM, Pravica V, Hajeer AH, McMahon R, Whorwell PJ, Sinnott PJ, Hutchinson IV: Interleukin-10 (IL-10) genotypes in inflammatory bowel disease. Tissue Antigens 1999, 54:386-390.

21. Awad MR, El-Gamel A, Hasleton P, Turner DM, Sinnott PJ, Hutchinson IV: Genotypic variation in the transforming growth factor-beta1 gene: association with transforming growth factor-beta1 production, fibrotic lung disease, and graft fibrosis after lung transplantation. Transplantation 1998, 66:1014-1020

22. Grainger DJ, Heathcote K, Chiano M, Snieder H, Kemp PR, Metcalfe JC, Carter ND, Spector TD: Genetic control of the circulating concentration of transforming growth factor type beta1. Hum Mol Genet 1999, 8:93-97.

23. Cantor MJ, Nickerson P, Bernstein CN: The role of cytokine gene polymorphism in determining disease susceptibility and phenotype in inflammatory bowel disease. Am J Gastroenterol 2005, 100:1134-1142.

24. Garcia-Gonzalez MA, Crusius JB, Strunk MH, Bouma G, Pérez-Centeno CM, Pals G, Meuwissen SG, Peña AS: TGF $\beta 1$ gene polymorphisms and inflammatory bowel disease. Immunogenetics 2000, 51:869-872.

25. Balding J, Livingstone WJ, Conroy J, Mynett-Johnson L, Weir DG, Mahmud N, Smith OP: Inflammatory bowel disease: the role of inflammatory cytokine gene polymorphisms. Mediators of Inflamm 2004, 13:181-187.

26. Klein W, Tromm A, Griga T, Fricke H, Folwaczny C, Hocke M, Eitner K, Marx M, Rune M, Epplen JT: The IL10 gene is not involved in the predisposition to inflammatory bowel disease. Electrophoresis 2000, 21:3578-3582.

27. Hong J, Leung E, Fraser AG, Merriman TR, Vishnu P, Krissansen GW: IL4, IL10, IL6 and TNF polymorphisms in New Zealand Caucasian Crohn's disease patients. In J Colorectal Dis 2008, 23:335-337.

28. Fernandez L, Martinez A, Mendoza JL, Urcelay E, Fernandez-Arquero M, Garcia-Perez J, Diaz-Rubio M, de la Concha EG: Interleukin -10 polymorphisms in Spanish patients with IBD. Inflamm Bowel Dis 2005, 11:739-743.

29. Mendoza UL, Urcelay E, Lana R, Martinez A, Taxonera C, de la Concha EG, Díaz-Rubio M: Polymorphisms in interleukin-10 gene according to mutations of NOD2/CARD15 gene and relation to phenotype in Spanish patients with Crohn's disease. World I Gastroenterol 2006, 12:443-448

30. Fowler EV, Eri R, Hume G, Johnstone S, Pandeya N, Lincoln D, Templeton D, Radford-Smith GL: TNFa and IL10 SNPs act together to predict disease behaviour in Crohn's disease. J Med Genet 2005, 42:523-528.

31. Bendicho MT, Guedes JC, Silva NN, Santana GO, Dos Santos RR, Lyra AC, Lyra LG, Meyer R, Lemaire DC: Polymorphism of cytokine genes (TGFbeta1, IFN-gamma, IL-6, IL-10, and TNF-alpha) in patients with chronic pancreatitis. Pancreas 2005, 30:333-336.

32. Pereira FA, Pinheiro da Silva NN, Rodart IF, Carmo TM, Lemaire DC, Reis MG: Association of TGF-beta1 codon 25 (G915C) polymorphism with hepatitis C virus infection. J Med Virol 2008, 80:58-64.

33. Hume GE, Fowler EV, Lincoln D, Eri R, Templeton D, Florin TH, Cavanaugh JA, Radford-Smith GL: Angiotensinogen and transforming growth factor beta1: novel genes in the pathogenesis of Crohn's disease. J Med Genet 2006, 43:e51.

34. Lennard-Jones JE: Scand J Gastroenterol 1989, 170:2-6. 
35. Silverberg MS, Satsangi J, Ahmad T, Arnott ID, Bernstein CN, Brant SR, Caprilli R, Colombel JF, Gasche C, Geboes K, Jewell DP, Karban A, Loftus EV $J$ r, Peña AS, Ridell RH, Sachar DB, Schreiber S, Steinhart AH, Targan SR, Vermeire S, Warren BF: Toward an integrated clinical, molecular and serological classification on inflammatory bowel disease: Report of a Working Party of 2005 Montreal Congress of Gastroenterology. Can J Gastroenterol 2005, 19:5-36.

36. Krieger $\mathrm{H}$, Morton NE, Mi MP, Azevêdo E, Freire-Maia A, Yasuda N: Racial admixture in north-eastern Brazil. Ann Hum Genet 1965, 29:113-125.

37. Raymond M, Rousset F: GENEPOP (version 1.2): population genetics software for exact tests and ecumenicism. J Hered 1995, 86:248-249.

38. Saito YA, Talley NJ, Andrade M, Petersen GM: Case-control genetic association studies in gastrointestinal disease: review and recommendations. Am J Gastroenterol 2006, 101:1379-1389.

39. Parra FC, Amado RC, Lambertucci JR, Rocha J, Antunes CM, Pena SDJ: Color and genomic ancestry in Brazilians. Proc Natl Acad Sci 2003, 100:177-182.

40. Cavalcante LN, Abe-Sandes K, Angelo AL, Machado TM, Lemaire DC, Mendes CM, Pinho JR, Malta F, Lyra LG, Lyra AC: IL28B polymorphisms are markers of therapy response and are influenced by genetic ancestry in chronic hepatitis C patients from an admixed population. Liver Int 2012, 32:476-486.

41. Aoki CA, Borchers AT, Li M, Flavell RA, Bowlus CL, Ansari AA, Gershwin ME: Transforming growth factor beta (TGF-beta) and autoimmunity. Autoimmun Rev 2005, 4:450-459.

42. Liberek A, Jakóbkiewick-Banecka J, Kloska A, Swiderska J, Kmiec Z, Luczak G, Wierzbicki P, Liberek T, Marek K, Plata-Nazar K, Sikorska-Wisniewska G, Kaminska B, Wegrzyn G: Clinical parameters of inflammatory bowel disease in children do not correlate with four common polymorphisms of the transforminggrowthfactor $\beta 1$ gene. Acta Biochim Pol 2011, 58:641-644.

43. Burke JP, Mulsow JJ, O'keane C, Docherty NG, Watson RW, O'Connell PR: Fibrogenesis in Crohn's disease. Am J Gastroenterol 2007, 102:439-448.

44. Van Assche G, Geboes K, Rutgeerts P: Medical therapy for Crohn's disease strictures. Inflamm Bowel Dis 2004, 10:55-60.

45. Kin TH, Kim BG, Shin HD, Kim JW, Kim CG, KIM JS, Jung HC, Song IS: Tumor necrosis factor-alpha and interleukin-10 gene polymorphisms in Korean patients with inflammatory bowel disease. Korean I Gastroenterol 2003, 42:377-386.

46. Garza-Gonzalez E, Pérez-Pérez Gl, Mendoza-Ibarra SI, Flores-Gutiérrez JP, Bosques-Padilla FJ: Genetic risk factors for inflammatory bowel disease in a North-eastern Mexican population. Inter I Immunogenet 2010, 37:355-359.

47. Zhu H, Lei X, Liu Q, Wang Y: Interleukin-10-1082A/G polymorphism and inflammatory bowel disease susceptibility: a meta-analysis based on 17,585 subjects. Cytokine 2013, 61:146-153.

48. Mocellin S, Panelli MC, Wang E, Nagorsen D, Marincola RM: The dual role of IL-10. Trends Immunol 2003, 24:36-43.

49. Amre DK, Mack DR, Morgans K, Israel D, Lambrette P, Costea I, Krupoves A Fegury H, Dong J, Grimard G, Deslandres C, Levy E, Seidman EG: Interleukin 10 (IL-10) gene variants and susceptibility for paediatric onset Crohn's disease. Aliment Pharmacol Ther 2009, 29:1025-1031.

\section{Submit your next manuscript to BioMed Central and take full advantage of:}

- Convenient online submission

- Thorough peer review

- No space constraints or color figure charges

- Immediate publication on acceptance

- Inclusion in PubMed, CAS, Scopus and Google Scholar

- Research which is freely available for redistribution

Submit your manuscript at www.biomedcentral.com/submit
C Biomed Central 